\section{POETISAS ULTRAMARINAS: PRENSA Y HOMONIMIA DE} AMBOS MUNDOS

OVERSEAS POETESSES: PRESS AND HOMONYMY IN BOTH WORLDS

Lilia Granillo Vázquez Universidad Autónoma Metropolitana Unidad Azcapotzalco

RESUMEN:

ABSTRACT:

Desde los estudios transatlánticos y con A gender point of view along with that of óptica de género, esta investigación revela la transatlantic studies leads this research the optica dhe cultura durat durante el siglo XIX. Además de documentar in Mexico and in Spain during the XIX los vínculos interculturales en ambos lados Century. Besides the evidence of intercultura del Atlántico, aborda la temática femenina connections between both sides of the y feminista y descubre conversaciones entre Atlantic, this paper also deals with feminine mujeres, el oficio poético compartido, la and feminist topics, and reveals conversations temática femenina y el ambiente literario y de among women, poetic skills and proficiency, historia de la prensa. all within the literary environment and as a contribution to the History of Press.

Palabras Claves:

Poetisas, historia de la prensa, siglo XIX, KEY wORD:
Female Poets, Press History, XIX Century, Transatlantic Studies, Mexico and Spain.
Durante una investigación en la cual buscaba poetisas románticas nacionales, inesperadamente me encontré con que numerosas escritoras españolas eran publicadas en prensas de la República Mexicana en el siglo XIX ${ }^{1}$. Tras disolver el prejuicio contra el estro poético de las mujeres en México -“la niña mexicana no ama la literatura nacional", declaraba en 1868, en El Monitor Republicano, el polígrafo y político Justo Sierra $^{2}-$ me intrigaba la posibilidad del intercambio poético, las prácticas intertextuales ultramarinas ${ }^{3}$. En contra de la evidencia de esta dinámica transcultural estaba la idea de que las comunicaciones entre los habitantes de la Península Ibérica y los de las ex-colonias americanas se habían deteriorado gravemente tras las guerras de Independencia. Más aún, se habían extinguido traslos intentos peninsulares de restaurar monarquías y alegar intervenciones. Ante las creencias generales de que los mexicanos odiaban a los españoles y que las mexicanas -excepción de Sor Juana- no escribían, me sorprendía la posibilidad de que existiera un "gusto" que prefigurara un "habitus" -en términos de Bourdieu ${ }^{4}$ - por incorporar en la prensa mexicana decimonónica, a poetisas del canon isabelino como Amalia Fenollosa, Josefina Massanés y Carolina Coronado.

Publicadas en los Panorama de las Señoritas Mexicanas o en la Semana de las Señoritas Mexicanas, estaban las escritoras de El Defensor del Bello Sexo (Madrid, 1845-1846) o de La Revista de Madrid (1850). Así, en ultramar, las alumnas de Alberto Lista, las socias del Liceo de Badajoz o del de Madrid y Valencia ${ }^{5}$ ocupaban lugares en El Liceo Hidalgo, la Sociedad Netzahualcóyotl o en El Parnaso Mexicano, junto a las veracruzanas Josefa Murillo y Josefina Pérez, o la poblana Rosa Carreto; todas ellas hijas, esposas y hermanas del liberalismo mexicano autor del canon La expresión nacional ${ }^{6}$. Dice Íñigo Sánchez, historiador del capital cultural femenino resguardado en la prensa española entre 1843 y 1868 , que

1 Cf. L. G.V., “Reescribir la historia de la poesía mexicana con óptica de género”, en Géneros, Revista del Centro Universitario de estudios de género de la Universidad de Colima, México, febrero de 1999, pp. 48ss; y Escribir como mujer entre hombres, poesía femenina mexicana del siglo XIX, en dictaminación. La mayoría de las publicaciones citadas en este artículo son periódicas. Las fuentes primarias del siglo XIX son todas hemerográficas.

2 Justo Sierra, "Conversaciones del domingo", publicada en El Monitor Republicano el 5 de abril de 1868, repr. en Obras Completas, volumen II, prosa literaria, México, UNAM, 1977, p. 69.

3 Cf. . L. G. V. , “Ecos y reverberaciones en la lírica femenina hispanoamericana”, en Luz Elena Zamudio, et al (Comp) III Congreso de literaturas latinoamericanas, México, Universidad

4 Pierre Bourdieu, Razones prácticas sobre la teoría de la acción, Barcelona, Anagrama, 1999.

5 Cf. Susan Kirkpatrick, "La mujer y la expansión de la prensa" en Las románticas, escritoras y subjetividad en España, 1835-1850, Ediciones Cátedra -Universidad de Valencia- Instituto de la Mujer, España, 1991, p. P. 76ss

6 José Luis Martínez, La expresión nacional, México, editorial Oasis, 1983. 
el canon isabelino presenta los rasgos de una competencia cultural que legitima en España, durante el reinado de Isabel II, los valores esteticos adscritos a la genuina literatura peninsular. El "habitus" dominante corre parejo a la consolidación de un historicismo romántico schlegeliano, a juicio de Derek Flitter, "profoundly Christian in inspiration and orientation, characterised by an intense idealism and a belief in the potency of national traditions" 7 .

Precisamente contra esta "genuina literatura peninsular" se manifestaba la literatura nacional mexicana. Para la nación recientemente emancipada del yugo colonial, convenía una expresión propia, lo más distante de la peninsular. No obstante, la notable empresa cultural de Guadalajara, por ejemplo, al frente de José López Portillo y Rojas, La República Literaria, publicación quincenal que exhibe capital cultural del Occidente de México desde marzo de 1886 hasta 1890, incluyó repetidas veces a la sevillana Blanca de los Ríos Nostench de Lamperez:

Tu nombre

Soñé contigo en dulce desvarío

y despierta a los rayos matinales,

escribí con el dedo en los cristales

tu nombre sobre gotas de rocío.

Y al desgarrar elcongelado velo

Y al desgarrar congelado velo

que era tu nombre azul el mismo cielo.

La Abeja, una revista del tipo prensa obrera, publicó en la Ciudad de México, el 10 de abril de 1875, "El desengaño" de la catalana Amalia Fenollosa: Es la vida del hombre sueño leve,

cercado de graciosas ilusiones,

cuya belleza mueve

a disfrutar de sus mentidos dones.

Son falaces los bienes, y constantes

las acerbas desgracias que apresuran

con rápidos instantes

una muerte fatal que siempre auguran.

Muerte que saca de su sueño al hombre,

presentando desnuda en aquel día

para que más se asombre,

7 Iñigo Sánchez Llama, Galería de escritoras isabelinas, La prensa periódica entre 1833 y 1895, España, Ediciones Cátedra -Universidad de Valencia- Instituto de la Mujer, 2000, pp. 16-17.

8 La República Literaria, Revista de ciencias, letras y bellas artes, (1886-1890) Redactores y propietarios: Esther Tapia de Castellanos, Antonio Zaragoza, José López Portillo y Rojas, Manuel Alvarez del Castillo, Guadalajara, México, Tip. De Luis Perez Verdia, a cargo de Ciro L. Guevara, el Hidalgo, Números 1 y 2, quincenal, año IV , marzo de 1889 a marzo de 1890 - Tom V, p. 248 la terrible verdad que le escondía. ${ }^{9}$ Años antes, en La Sociedad, revista que convocaba "el espiritu de asociación,

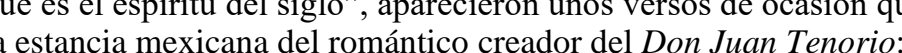

Zorrilla, ¿qué ha sucedido?

¿Qué nos tienes que decir?

¿Qué ha pasado? ¿Qué has oído?

¿Dónde anduviste perdido?

¿Cómo tardaste en venir?

¿Qué jardín te dio la flo

para libar su ambrosía?

¿Qué arroyo te dio el rumor?

¿Qué luna te dio su amor para cantar tu poesía?

¿Es verdad que solo y triste

tu lira llevando en suma

allá muy lejos te fuiste,

y que pisaste y viste

tierra de Moctezuma?

Más aún, desde la primera edición (1838) del tradicional Calendario de las Señoritas Mexicanas, anuario de Mariano Galván que sigue apareciendo hoy día, encontré romances anónimos con relatos de princesas moras, cautivos y otros temas moriscos que eran evidencia de la continuidad en el intercambio cultural entre España y la nación que desde principios de siglo había renunciado a ser considerada como la Nueva España.
El de la Cruz Colorada
Oriental
Dime tú, el rey de los moros,
el de los bellos jardines,
el de los ricos tesoros,
el de los cien paladines,
el de los cien paladines,
con sus agujas labradas,
con sus agujas labradas,
el rey de las medias lunas,
de los reyes soberano,
el de la Alhambra dorada,
el de la hermosa Granada,
¿En dónde está mi cristiano,
el de la cruz colorada? ${ }^{11}$

La presencia en el México Independiente, en el de Las Intervenciones y el Triunfo de la Reforma Liberal, de producciones culturales españolas entreveradas con las nacionales, me sorprendía aun más pues los liberales -radicales- eran quienes las

9 La Abeja, Revista bisemanal de conocimientos utiles dedicados a la clase obrera e industrial Ciudad de México, ed. J. M. Aguilar Ortiz, Tip. De F. Monsalvo, Perpetua № $8^{1 / 2}$, Librería $1^{a}$ de Sto. Domingo, № 5, abril 10 de 1875, T.II, N. 28. p.2.

10 La Sociedad, periódico político y literario, México, Imprenta de Andrade y Escalante, (1860-1866) nov. 8 de 1866, $3^{\mathrm{a}}$ ep. T.IV, №1214, p. 2 .

11 Calendario (s) de las Señoritas megicanas para el año de 1838, dispuesto por Mariano Galván, en la librería del editor, Portal de agustinos 3, Megico (sic.), pp. 49 a 55. 
publicaban en los órganos de difusión de sus ideas. En 1862, el Conde de Reus, mejor conocido en México como "General Prim", había informado, en su calidad de jefe de la fuerza expedicionaria española que "la monarquía no se puede ya aclimatar en México; podrá imponerse, pero duraría el tiempo que dure la ocupación (...) (satisfaciendo) mi deber de buen español, de hidalgo castellano y de hombre leal, me retiro (de México) con las tropas que el gobierno se dignó poner a mis órdenes."12

Tras la derrota de la intervención francesa y el triunfo de la República Restaurada, en 1868, Ignacio Manuel Altamirano, el presidente de la República de las Letras Mexicanas, desplegaba en el semanario El Renacimiento, lo que la historia de la literatura mexicana denomina "el proyecto de literatura nacional": "Podemos tener y de hecho tenemos una literatura nacional mexicana (...) que rechaza la imitación servil de la literatura española (...) pues la poesía y la novela mexicanas deben ser vírgenes, virtuosas, originales, como lo son nuestro suelo, nuestras montañas, nuestra vegetación. (...) En nuestra historia hay bastantes asuntos para enriquecer con ellos la poesía heroica."13

$\mathrm{Al}$ respecto, Carlos M. Rama comenta que Altamirano y los discípulos de la “doctrina nacionalista", reconocían que la lengua de la literatura española era la misma de la mexicana, sin embargo, "Altamirano se alzaba contra la actitud con la que "todavía recibimos de la metrópoli preceptos comerciales, industriales, agrícolas y literarios, con el mismo temor y reverencia con que recibían nuestros abuelos las antiguas reales cédulas en que los déspotas nombraban virreyes, prescribían fiestas o daban la noticia interesante del embarazo de la reina." 14

Mientras recopilaba muestras de textos españoles en la prensa que tanto contribuyó a la Independencia de las antiguas colonias, una y otra vez recordaba el antihispanismo de liberales mexicanos como Francisco Zarco, paladín de la libertad de expresión. De la literatura colonial, se valoraba únicamente la figura de Juan Ruíz de Alarcón, el dramaturgo mexicano que fuera tan mal recibido en la Corte Madrileña. Zarco se expresaba así en el discurso que inaugura su presidencia del Liceo Hidalgo, sucesor de la Academia de Letrán la otra asociación literaria más reputada del siglo XIX: “Ruíz de Alarcón tuvo mucho que sufrir, se vio herido por el odio y la envidia de los españoles; muchas de sus obras se perdieron y ahora la gloria del célebre poeta nos es disputada por la España." ${ }^{15}$ Mientras que al año siguiente repudia el españolismo de Sor Juana 12 Rep. Por Ernesto de la Torre Villar et al., Historia documental de México, México, UNAM, 1974 t. II, pp. 317-8.

13 Cit. por José Luis Martínez, Op. Cit., en "La polémica Altamirano-Pimentel" en La expresión nacional, México, Editorial Oasis, 1983, p.75ss. Ct. Ruedas de la Serna, Jorge, (ed.) Los orígenes de la visión paradisíaca de la naturaleza mexicana, México, UNAM, 1987.

14 Cit por Carlos M. Rama, Historia de las relaciones culturales entre Europa y la América Latina. Siglo XIX, México, Fondo de Cultura Económica, pp. 269-70.

15 Francisco Zarco, “Discurso sobre el objeto de la literatura en México”, La Iustración Mexicana, T 1., pp. 162, México, 1852 . y considera su poesía como "ocioso juego de palabrerías", algo de procedencia peninsular: "Sor Juana Inés de la Cruz, encomiada en su tiempo, adolece de todos los defectos y del mal gusto que cuando ella escribía se notaba en todo los poetas españoles."16

El rechazo de la herencia española lleva al encomio de obras de asunto medieval británico, europeo, por ejemplo, en la dramaturgia de Fernando Calderón, autor de famosas comedias como El Torneo, La Vuelta del Cruzado y Ana Bolena. En 1860, de él decía Francisco González Bocanegra, criollo autor de la letra del actual Himno Nacional Mexicano, quien de niño vivió en Cádiz, pues su padre, militar español, fue uno de los expulsados en 1826: “Las obras del señor Calderón honran la literatura de nuestra patria, y si las dramáticas no son del todo perfectas, revelan desde luego las felices disposiciones de que estaba dotado su autor; ellas son una prueba de que la literatura había hecho en el México Independiente, en pocos años, progresos mucho mayores que en todo el tiempo de la dominación española." ${ }^{17}$ En 1865, se produce un discurso que abiertamente propugna por "La desespañolización". El conocido radica Ignacio Ramírez, El Nigromante, en sentida proclama confirmaba la tesis de la total separación entre México y España, y su genial diatriba llegaba incluso a promover la desespañolización de Emilio Castelar, invitándolo a mudarse a México (¿qué hacía un liberal, un republicano como Castelar, entre aquellos insensatos que insistían en ser monárquicos?).

Desde España, Castelar había preguntado retóricamente: “¿Renegáis americanos de esta nación generosa que tantos timbres tiene en su historia, tantas prendas en su carácter, tantos fulgores en su civilización (...) Renegáis de esta país que ha fundado vuestros puertos, que ha erigido vuestros templos, que os ha dado su sangre, que ha difundido su alma en vuestra alma, que os ha enseñado a hablar la más hermosa, la más sonora de las lenguas?" México atravesaba entonces por la Intervención Francesa, y la respuesta de Ramírez es fulminante:

Renegamos los mexicanos de la patria de Usted (...) del mismo modo y por las mismas razones que Usted reniega de ella. (...) ¿A qué época de España quiere que pertenezcamos? ¿Imitaremos la España actual donde Usted, admirable escritor, es visto como un paria? (...) No, Usted no canoniza el robo del guano, ni los asesinatos de Santo Domingo, ni la esclavitud de Cuba; llamándose Usted demócrata ha dicho sobre la España de hoy: ¡Anatema! (...) Nos designará Usted por ventura la Edad Media? El tipo más puro de aquella ¿́sosa nos lo consu D. Qujote, el más pur por que ente caball puro de aquella eco y no un bandido. (..) Renes un (...) La España que Usted ama no existe ni ha existido jamás; el talento de Usted la engendra en su

16 Francisco Zarco, Estado de la Literatura en México", La Ilustración Mexicana, T. III, p. 6. México, 1852.

17 Francisco González Bocanegra, “Discurso sobre la poesía nacional”, 1860, rep. en Jorge Ruedas de la Serna, coord. La misión del escritor, ensayos mexicanos del siglo XIX, México, UNAM, 1996, p. 39 
alma democrática. (...) Y se deslumbra Usted con la civilización que le desea, pero entretanto, para sus paisanos, Usted no es más que el Don Quijote del progreso. ${ }^{18}$

También se me venían a la mente las nociones de negación de España, escritas por Octavio Paz y el contraste entre la independencia estadounidense y la mexicana:

El movimiento norteamericano fue una consecuencia de las ideas, las instituciones y los principios ingleses trasplantados al nuevo continente. La separación de Inglaterra no fue una negación de Inglaterra, fue una afirmación de los principios y creencias que habían fundado a las primeras colonias, especialmente el de la libertad religiosa. (...) La Revolución de Independencia separó a los Estados Unidos de Inglaterra, pero no los cambió ni se propuso cambiar su religión, su cultura y los principios que habín fundado a la nación. La relación de las colonias cuispanomerican os principios que fundaron a nuestros pais absoluta, el neotomismo y, al mediar el siglo XVII, el "despotismo ilustrado" de Carlos III. La independencia hispanoamericana fue un movimiento no sólo de separación, sino de negación de España. Fue una verdadera revolución (...) es decir, fue una tentativa por cambiar un sistema por otro: el régimen monárquico español absolutista y católico, por uno republicano, democrático y liberal. ${ }^{19}$

Abundan los textos españoles reproducidos en una prensa cuyo papel ante las emergentes literaturas nacionales postindependentistas fue decisivo en la creación de las nuevas repúblicas. A pesar de que se proclamara lo contrario. Trinidad Barrera López expresa hoy, desde España, la tesis separacionista: "No parece haber duda que desde el discurso crítico de la segunda mitad del siglo XVIII hasta nuestros días la literatura hispanoamericana ha tenido como consigna la independencia literaria." ${ }^{20}$ Altamirano, ya en el Porfiriato, escribe su Revistas Literarias de México (1821-1867) trazando la emancipación cultural desde el año mismo de la consumación de la Independencia las Letras Patrias de M. Sánchez Mármol (1901) confirman esa emancipación. En 1990, Rosalba Campa propone que la tendencia del periodismo como agente de una cultura propia, ajena a lo peninsular, era de índole continental, pues en el XIX se trababa el "ferviente combate sobre la necesidad de una palabra propia, (...) en el período subsiguiente a la Independencia (...) (se caracterizó por) años que en salones

18 Ma. Elena Victoria, “Ignacio Ramírez, La desespañolización” en Jorge Ruedas de la Serna, coord. La misión del escritor, ensayos mexicanos del siglo XIX, México, UNAM, 1996, p. 181. La modern editora de tan notable discurso asegura que no se ha encontrado el texto de Castelar.

19 Octavio Paz, cit. Por Carlos M. Rama, Historia de las relaciones culturales entre España y la América Latina. Siglo XIX, México, Fondo de Cultura Económica, 1982, p. 25.

20 T. Barrera López, "La identidad cultural americana a finales del siglo XIX", Andalucía y América en el siglo XIX, T. II, Escuela de estudios hispanoameicanos-Universidad hispanoamericana de Santa María La Rábida, Sevilla, 1986, p. 207 y academias, en periódicos y certámenes literarios se discute sobre 'el deber ser' de las literaturas nacionales de Hispanoamérica." ${ }^{21}$

Vista la presencia "de los valores estéticos adscritos a la genuina literatura peninsular" en una prensa que aspiraba a la "independencia literaria", me parece que existe una dialéctica cultural de ruptura y continuidad, una relación polémica entre México y España, perceptible en la historia de la prensa mexicana, tal y como la propone Luis Mario Schneider en su obra Ruptura y continuidad, la literatura mexicana en polémica ${ }^{22}$, para la construcción de la literatura nacional. Cada vez encuentro más y mejores evidencias de esta dinámica cultural que enmienda, o al menos problematiza, la noción de separación, de negación de España. Y pese a que la separación haya sido política, incluso religiosa y étnica, tantos textos españoles en prensa mexicana y tantas escritoras mexicanas en recuentos hispanos, hablan de la existencia de un capital cultural compartido entre México y España, cuya circulación se realiza en el espacio simbólico de la prensa, de una prensa canalizada entre ambos mundos. Lo confirman indicios y testimonios peninsulares muy recientes. Supongo que tal existencia puede extenderse al resto de América Latina.

En su actual recuento de Escritoras españolas del siglo XIX, Manual bio-bibliográfico, Carmen Simón Palmer incorpora a varias escritoras mexicanas dando por hecho que son españolas. Así, junto a la Pardo Bazán y Rosalía de Castro, a la Baronesa de Wilson y a Rosario de Acuña, están la mexiquense Laura Méndez de Cuenca, Rosa Carreto, Rosa Espino, la veracruzana Josefina Pérez -esposa del insigne periodista Vicente García Torres, de familia de editores e impresores-, la jalisciense Josefa Letechipía y las yucatecas Cristina Farfán y Dolores Correa Zapata, entre otras. No se trata del criterio filológico pan-hispanista (algunos lo identificarían como imperialismo cultural) que incluye a Sor Juana en la literatura española. Asegura Simón Palmer en su "Introducción" que:

este repertorio incluye a las escritoras cuya primera producción se publicó entre los años 1832 y 1900, por lo que figuran algunas que viven hasta bien entrado el Pue Rico, por Puerto Rico, por considerar que es más lógico que se integren en la literatura de lo países en que vivieron. La excepción es Gertrudis Gómez de Avellaneda porque su obra se hizo en España. ${ }^{23}$

1 R. Campa, "Búsqueda de categorías críticas en el centro de estudios literarios, México, UNAM, 1990, p. 23.

22 Luis Mario Schneider, Ruptura y continuidad, la literatura mexicana en polémica, México, Fondo de Cultura Económica, 1973.

23 María del Carmen Simón Palmer, Escritoras españolas del siglo XIX: manual bio-bibliográfico Madrid, Castalia, 1991, p. Ix. 
Pese a las buenas intenciones, la bibliógrafa incluye autoras de nacionalidad mexicana. Más que la equivocación, interesa aquí destacar que el rescate de las escritoras se elaboró mayoritariamente con base en la revisión de publicaciones periódicas, espacio público donde circula aquel capital iberoamericano. Veamos el caso de la yucateca Cristina Farfán, cuya obra fue difundida en la República por la publicación quincenal El Renacimiento (1868), que dirigía, en la Ciudad de México, el propio Altamirano, y por la revista mensual de Mérida, La Siempreviva(1872), órgano de la asociación del mismo nombre. En España, La Ilustración de Barcelona (1887) y el Álbum-Iberoamericano de Madrid (1893), retransmitieron la obra de esa mexicana. Mientras que Rosa Espino -toda ella una ficción trasatlántica de Vicente Riva Palacio ${ }^{24}$ - publicó primero siempre en El Imparcial de la Ciudad de México, de cuyas prensas salía para ser republicada en las provincias y allende el mar; en España se encuentra como "colaboradora" en La Ilustración Ibérica de Barcelona, hacia 1886. Más allá de una confusión, la inserción de las románticas mexicanas en el acervo de escritoras españolas decimonónicas responde a un proceso de identificación cultural, de afinidades descubiertas, de encuentros de alteridades. Precisamente la práctica de las redacciones de periódicos y revistas decimonónicas, de recurrir al préstamo cultural -sólo se debatió la noción de plagio dentro de la polémica de la originalidad de las literaturas latinoamericanas-, o intercultural, para mayor precisión, me llevó a pensar que este capital cultural se desplaza indistintamente entre el Viejo y el Nuevo Mundo entre Europa y América. La región simbólica donde se exhibe, almacena y recicla ese capital con mayor dinamismo es el espacio público impreso cuya característica es la periodicidad, una cierta frecuencia, sea bisemanal, diaria, anual. El desplazamiento de mensajes en publicaciones periódicas en lengua española constituye un corredor cultural, un ámbito civilizatorio que emite, consume, reparte, distribuye, cierto capital. Este espacio de lo imaginario, región simbólica de "ambos mundos", constituye un canal donde circulan noticias, ideas, propuestas, altercados, estéticas, en fin, toda suerte de significados intercambiados entre emisores y receptores que se ubican en

24 Tras el seudónimo de Rosa Espino se ocultó durante años el general Vicente Riva Palacio, quien fue embajador de Mérxico, en Madrid, de 1886 a 1896. Rosa Espino es un heterónimo femenino, un caso de travestismo literario que permitio al General disfrazarse de una "niña poetisa de Guadalajara", cuyos poemas aparecian en la seccion "Variedades" de El Imparcial. No me extraña que la supercheria genial, como la llama José Luis Martinez, Op. Cit, haya atrapado también a la notable erudita Simón Palmer. "Rosita” logró engañar a la cultura letrada nacional por varios años. Fue "distinguida" en homenaje público, con un diploma de socia honoraria del Liceo Hidalgo, la máxima academia literaria del momento (diciembre de 1872), ante Ignacio Ramírez, Ignacio Manuel Altamirano, Francisco Pimentel, José María Vigil, Juan A. Mateos, Manuel Acuña, Justo y Santiago Sierra. El literato español Anselmo de La Portilla propuso la distinción y es famoso el comentario que dirigió inocentemente a Riva Palacio la noche de la premiación: "Para escribir como Rosa Espino escribe, se necesita tener alma de mujer, y de mujer virgen. Esa ternura y ese sentimiento no lo expresa así jamás un hombre". CF. Luis Mario Schneider, "Cuando el General fue una Rosa", en Homenaje a Clementina Días y de Ovando, devoción a la Universidad y la cultura, México, UNAM., 1993, p. 140 ambos lados del Atlántico. Con esto, puede ya distinguirse el espacio, la región que llamaremos "Trasatlántica". Hace unas décadas que un grupo de expertos comparte la noción de que "the Atlantic Region has been defined by a long history of economic, political and security links, migration and cultural cross fertilization and the growing intensity of interdependence" ${ }^{25}$

Quienes acudían al corredor, quienes siguen acudiendo, periodistas, redactores, editores y lectores, se alternan la producción y la recepción de ese capital. Así, ciertas prácticas editoriales ultramarinas se constituyen dentro del espacio sociocultural que llamo "corredor cultural transatlántico" por donde circulan mensajes impresos con naturaleza periódica. Estas prácticas comunicativas, estos mensajes, significados, contextos, cotextos, en fin todo producto de aquella expresividad, que se vincule con tal corredor cultural constituye un discurso que puede llamarse "prensa de ambos mundos"

DEBATES DE LITERATOS, HISTORIADORES Y PERIODISTAS: HISTORIOGRAFÍAS EN AMBOS ADOS DEL ATLÁNTICO

Escribir la historia de la prensa en lengua española es ocupación muy reciente, motivada por el advenimiento del llamado "Siglo de las comunicaciones" y como resultado del establecimiento, en escuelas y facultades, de las llamadas ciencias de la comunicación o de la información, todo ello en los últimos cincuenta años. Tal ocupación ha precipitado a historiadores y a comunicólogos de las naciones hispanohablantes a debatir el nombre mismo: ¿historia de la prensa, historia del periodismo o historia de la comunicación social? A las cuestiones académicas que discuten tanto el objeto de estudio -prácticas sociales o estilísticas; escritores; lectores o comunidades- como el rango disciplinar -filología o lingüística, historia o sociología, antropología cultural o publicística-, se añaden las teóricas: análisis del discurso, iconografía, teoría de la recepción, sociología de la opinión pública, en fin.

Tradicionalmente, los periódicos han sido considerados fuentes documentales para escribir historias sociales, de la literatura, de la cultura. En México existe la afición de los investigadores por elaborar índices de las revistas literarias, por ejemplo, a fin de constituir corpus de literatura o estudiar movimientos y escuelas a partir de sus órganos de difusión. Además de índices y numerosas ediciones anotadas, facsimilares, de periódicos y revistas decimonónicas a cargo de investigadores del Instituto de Investigaciones bibliográficas (UNAM), vinculado a la Hemeroteca y Biblioteca Nacionales ${ }^{26}$, están las publicaciones de la "Escuela de Periodismo Carlos Septién

25 Transatlantic Studies Society Journal, U. Of Dundee, Scotland.

26 José Ignacio Bartolache, Mercurio Volante (1772-1773), Int. Roberto Moreno, México, UNAM, 1983; La ilustración potosina, semanario de literatura, poesía, novelas, noticias, descubrimiento variedades, modas y avisos, por José T. de Cuéllar y José María Flores Verdad, tomo I, 1869, San 
García" y del "Club Primera Plana"; y los numerosos tesistas, becarios y becarias que realizan los índices de periódicos y revistas ${ }^{27}$ así como el rescate que desde la Universidad de Guadalajara realizan los equipos de Celia del Palacio y Magdalena González Casillas ${ }^{28}$. En el Instituto de Estudios Históricos Dr. José María Luis Mora se ejecutan dos grandes investigaciones colectivas a cargo de Laura Suárez de la Torre María Esther Pérez Salas y Nicole Giron, acerca de editores y empresas periodísticas del siglo XIX. Uno que se ocupa de los grandes impresores como Ignacio Cumplido, Vicente García Torres, Juan N. Barbero, realizó en 2000, el Coloquio “Empresa y cultura en tinta y papel" que congregó a una treintena de investigadores de todos los rincones del país ${ }^{29}$; y otro, acerca de folletería, pasquines y panfletos desde 1805 , año de inicio de El Diario de México, que convoca ya a muchos recopiladores de estas formas incipientes y ancilares de prensa.

Con todo, no ha sido superado el manual clásico de historia de la prensa, encabezado por María del Carmen Ruíz Castañeda, quien fuera iniciadora de la cátedra de historia del periodismo en la UNAM, y directora de la Hemeroteca y Biblioteca Nacionales y del instituto de investigaciones bibliográficas. Su El periodismo en México, 500 años de historia compite en erudición con el notable catálogo de seudónimos, anagramas e iniciales de escritores que han publicado en México mayoritariamente en la prensa. Investigación hemerográfica a la cual se une un Diccionario biobliográfico de seudónimos, verdadera enciclopedia de las plumas, sin limitarse a las mexicanas, que han sido publicadas en la prensa que se conserva en el Circuito Cultural Universitario ${ }^{30}$.

Luis Potosí, México, edición facismilar de Ana Elena Díaz Alejo, estudio preliminar, notas, índices y cuadros de Belen Clark de Lara, México, UNAM, 1989. Heredia, José María, La Minerva, periódico, notas e índices de M. C Ruíz Castañeda, México, UNAM, 1972. El Renacimiento, Periódico Literario, T. I y II, editores, Ignacio Manuel Altamirano y Gonzalo A. Esteva,., México, 1869, edición facsimilar y presentación de Huberto Batis, México, UNAM, 1993; El Recreo de las familias, México, Librería de Galván, 1838, nueva edición facsimilar y estudio preliminar de M. C. Ruíz Castañeda, índices po Sergio Márquez Acevedo, México, UNAM, 1995, El Iris, periódico crítico y literario, por Linati, Galli y Heredia , $2^{\mathrm{a}}$ edición, Intr. por Maria Del Carmen Ruíz Castañeda, "El Iris, primera revista literari del México independiente", e índice por Luis Mario Schnedier, México, UNAM, I- I. B. 1988, T. I y II, del sábado 4 de febrero de 1826 al miércoles 26 de julio de 1826.

27 Cf. www.unam.mx el programa “TESIUNAM”. Servicios electrónicos de información, enlaces y accesos a catálogos electrónicos en www.cosei.uam.mx

28 C. Del Palacio, (ed.), El ensayo literario, 1852, estudio preliminar e índices, $2^{a}$ edición Guadalajara México, Secretaría de cultura de Jalisco, 1994. C. del Palacio, La primera generación romántica de Guadalajara, La falange de estudio, Guadalajara, México, Universidad de Guadalajara, 1993. en el Siglo XIX, Guadalajara, Jalisco, México, Gob. de Jalisco, Sría. Gral. Unidad editorial, 1987

29 Laura B. Suárez de la Torre, “Empresarios - editores en la Ciudad de México, 1830-1855”, Boletín del Instituto Mora, Nva. Época, vol. 9, No. 25. Enero-abril de 1999, México.

30 M. C. Ruíz Castañeda y Luis Reed Torres, El Periodismo en México, 500 Años de Historia, $3^{a}$ ed. México, Club Primera Plana-EDAMEX, 1995, 373 pp.; M. C. Ruíz Castañeda y Sergio Márquez Acevedo, Catálogo de seudónimos, anagramas, iniciales y otros alias usados por escritores mexicanos y extranjeros que han publicado en México, México, UNAM, 1985 ; M.C. Ruiz Castaneda y S. Márquez
Acevedo, Correcciones al catálogo de seudónimos, anagramas, iniciales y otros alias usados por
Desde las ciencias de la comunicación y la semiología investigan Mabel Piccini, Florence Toussaint y Horacio Guajardo, entre otros que abordan la historia y crítica de la opinión pública, las teorías de las representaciones, las de lenguaje e ideología, semiótica, etcétera ${ }^{31}$. La historia de la prensa aparece también en las enciclopedias culturales, como la oficial coordinada por José Rogelio Álvarez o la del polígrafo Humberto Mussachio ${ }^{32}$. La globalización del interés latinoamericano por historiar la prensa quedó de manifiesto en la reunión anual de la Society for Latin American Studies, academia británica que en su conferencia de 2001 contó con una mesa de 4 sesiones, organizada por Laura Llul: concurrieron historiadores de México, de Argentina, de Estados Unidos y de Brasil ${ }^{33}$. Una ojeada a la historiografía española revela una rica

escritores mexicanos y extranjeros que han publicado en México, México, UNAM, 1990. M.C. Ruíz Castañeda y S. Marqués Acevedo, Diccionario biobligráfico de seudónimos usados por escritores mexicanos y extranjeros que han publicado en México, México, UNAM, 2000. Cito investigaciones anteriores: M.C. Ruíz Castañeda, Periodismo político de la Reforma en la Ciudad de México 18541861, México, Instituto de Investigaciones Sociales, UNAM, 1956, y La prensa periódica en torno a la constitución de 1857, México, I.I.S., UNAM, 1959; Armando Bartra, et al., Las publicaciones periódicas y la historia de México, Conferencias Magistrales, 50 aniversario de la Hemeroteca Nacional, México, UNAM, 1995; Rafael Carrasco Puente y Ma. Teresa Camarillo Carbajal, Hemerografía del periodismo mexicano, México, UNAM, 1989, Enrique Cordero y Torres, Historia del periodismo en Puebla (1820-1892), Pue. México, ed. La Bohemia Poblana, 1974, Gerald Mc Gowen, Prensa y poder, 1854 1857, México, El Colegio de México, 1978. Ma. Del Carmen Reyna, La prensa censurada durante el siglo XIX, México, Secretaría de Educación Pública. 1976, Stanley Robert Ross, Fuentes de la historia contemporánea de México, Periódicos y revistas, México, El Colegio de México, 1965, 2 vols.; José Bravo Ugarte, Periodistas y periódicos mexicanos, México, Ed. Jus, 1966; Diego Arenas Guzmán, triodsmo en la Revolución Mexicana (1876-1980), México, Biblioteca del Instituto del Instituto Nacional de Estudios Historicos de la Revolución Mexicana, 1966; Carlos J. Sierra, La prensa libera Edit. Porrúa, 1955

31 Horacio Guajardo, Teoría de la comunicación social, México, ediciones Gernika, 1986; Mabe Piccini, et. al., La imagen del tejedor. Lenguajes y politicas de comunicación, México, ediciones G. Gil y FLACSO, 1987; Raúl Trejo Delarbe, "La ética y los valores en el periodismo" en Juliana González y Josú Landa, (Coord.), Los valores humanos en México, México, Siglo XXI, 1997. Investigaciones relacionadas: Nora Pérez Rayon, Mentalidad y cultura en el cambio de siglo: percepciones y valore a través de la Gran Prensa Capitalina, México 1900, México, Porrúa, 2001 (en prensa), Consolación Salas, Vanidades masculinas: Las revistas masculinas mexicanas 1900-1989, tesis inédita de periodismo y comunicación colectiva, México, UNAM, 1992.

32 José Rogelio Álvarez (coord.) "Periodismo", Enciclopedia de México, México, Secretaría de Educación Pública 1992 V. 9. H.M "Periodsmo", Diccionario enciclopédico de México, v. II , México, Planeta, 1997 (11 ${ }^{\mathrm{a}}$ reimpr, $1^{\mathrm{a}}$ ed marzo de 1990).

33 SLAS 2001, Annual Meeting and Conferece, 1th-8th april, 2001, U. Of Birmingham. Conference Session 12: Lartin American Press History, Convenor: Laura Llul, Universidad Nacional del Sur Bahía Blanca, Argentina. Ponencias de México: Ignacio Cumplido, iniciador de las publicaciones periódicas literarias mexicanas en el siglo XIX, M.E. Pérez Salas, Instituto Mora; Intercultural exchange and satire in "prensa de ambos mundos": El Alacrán y El Acabose México and Spain, 1899, L.G.V., UAM; Caricatura y formación del espacio público periodístico en México (Siglo XIX) Laurence Coudart, U. Autónoma del Estado de Morelos. De USA: Print Publishing in Viceregal Mexico City, Kelly Donahue-Wallace, U. North Texas. De Argentina: Dios y el diablo en la tierra de Darwin: disputas editoriales, confrontaciones política en la prensa norpatagónica (1932-1936), Leticia Priseli, U. De Buenos Aires y U. Nal. De Comahue; Prensa y política en la "Liverpool Argentina": E feminista? Acercamiento a la práctica periodística de las mujeres argentinas a partir de un estudio 
miscelánea de textos que tocan el mundo de la prensa en el siglo XIX, época en que se gesta la comunicación social en publicaciones periódicas. Ya desde 1986, Jesús Timoteo Álvarez escribía con oportunidad académica "algunas puntualizaciones e hipótesis en torno a la historiografía española especializada en prensa", y se lamentaba de que: "las ciencias sociales en general y los historiadores hasta hace unos años han despreciado el fenómeno informativo y apenas han recurrido a él en la explicación de las sociedades, ni siquiera en las contemporáneas." ${ }^{34}$

Casi una generación después, los agravios del desprecio han sido superados laboriosamente. Además de los trabajos de Marcelino Tobajas ${ }^{35}$, entre los más recientes destaca la historia general del periodismo español, en varios volúmenes, obra de María de la Cruz Seoane y María Dolores Sáiz ${ }^{36}$. En cuanto a investigaciones monográficas o de prensa regional y local, están los catálogos o "martirologios" de periodistas como los de José Altabella, que retoma los trabajos de Ossorio y Bernard, o, por ejemplo, los de Manuel Moreno Alonso acerca de las tesis emancipadoras de Blanco White en su periódico $E l E s p a n ̃ o l{ }^{37}$. Por cierto que vida y obra de José Altabella, el primer catedrático español de historia del periodismo, resumen el dinamismo actual de los historiadores de lo informativo y el Libro Homenaje a José Altabella es un buen compendio. Existe una tendencia peninsular a escribir historia de la prensa de Iberoamérica en torno a la guerra hispano-cubana de 1898, al llamado "Desastre", y a la imagen de España en América Latina. Me refiero a los trabajos actuales de estudiosos como María Rosario Sevilla Soler, Domingo Muñoz Bort, María José Ruiz Acosta y Rafael Sánchez Mantero,

de caso. Bahía Blanca 1880-1946, Lucía Bracamonte, U. Nal. del Sur; La prensa como vehículo de construcción de un modelo educativo, M. Ramírez, U. Nal. Del Sur; Imprensa paranaense pós 1964 da construcao a desconstrucao do discurso, Ana Lucia Silva, U. Do Paraná; The press and the society, The role of the press in articulation of human rights in Latin America, Tapati Deb, Centre for Latin American Studies, Londres.

34 J. Timoteo Álvarez, "Algunas puntualizaciones..." en La prensa española durante el siglo XIX Actas de las I Jornadas de especialistas en prensa regional y local, Almería, Instituto de estudios almerienses, 1987.

35 M. Tobajas, El periodismo español (notas para su historia), Madrid, ed. Forja, 1984

36 M.C. Seoane, Historia del periodismo en España, Alianza Editorial, Madrid, 1983, María Cruz Seoane y María Dolores Sáiz, Historia del periodismo en España, v. 3, El siglo XX: 1898-1936, Madrid, Alianza Editorial, 1998.

37 Manuel Ossorio y Bernard, Ensayo de un catálogo de periodistas españoles del siglo XIX, Imprenta y litografía de J. Palacios, 1903. José Altabella, "Notas para un elenco del martirologio de periodistas del siglo XIX", en La prensa en la Revolución Liberal, España, Portugal y América Latina, Madrid, del siglo XIX" en La prensa en la Revolución Liberal, España, Portugal y América Latina, Madrid, americanas y la política de Cádiz (1810-1814)" en El Español de Blanco White, Andalucia y Ameríca en el siglo XIX, Actas de las V Jornadas de Andalucía en América, Sevilla, Escuela de Estudios Hispanoamericanos-Universidad Hispanoamericana Santa María de la Rábida, 1984.

38 Rosario Sevilla Soler,"La crisis del 98 y la sátira en la prensa sevillana", Andalucía y América en el siglo XIX; R. Sevilla Soler, "España-Cuba 1898: Prensa y opinión pública", Cuba entre do Andalucía y América en el siglo XIX, ...Op. Cit; M. J. Ruíz Acosta, Sevilla e Hispanoamérica, Prensa publicados gracias a los afanes de la Escuela de Estudios Hispanoamericanos y de la hispalense Facultad de Ciencias de la Información, ambas en Sevilla. Dignos de mención son los trabajos realizados en las I Jornadas de especialistas en prensa regional y local (Almería, 1987) y en el coloquio La prensa en la Revolución Liberal, España, Portugal y América Latina, cuyos resultados fueron publicados por la Universidad Complutense en 1983. En cuanto a postulados teóricos y metodológicos destacan los de Antonio Elorza, especialista en espacios públicos e ideologías, sintetizados en "Las ideologías políticas y su historia" y las concepciones del citado J. Timoteo ${ }^{39}$, cuya percepción de los cambios históricos en los órdenes informativos bien pueden extenderse hacia la prensa latinoamericana Investigaciones como "La Revista de España y del ExtranjeroRevista de España, de Indias y del Extranjero, 1842-1847: sobre la construcción del eje moderado Valencia-Madrid en el proceso revolucionario español"40, confirman la idea del corredor cultural transatlántico materializado en la prensa del XIX. En los volúmenes de historia de la prensa de España está siempre presente la información emitida en América o retransmitida allá. También en las entradas de "Cultura isabelina" o "prensa política" en obras de consulta como la Historia General de España y América o el Diccionario de Historia de España, respectivamente. ${ }^{41}$

La historia más completa de la prensa como institución cultural en América Latina es obra del historiador español Antonio Checa Godoy. ${ }^{42}$ Con acierto, divide su objeto de estudio por regiones y etapas políticas, sin desligar los países de una dinámica continental. En este manual, se encuentran los orígenes y años previos a la emancipación, notas acerca del periodismo insurgente en México, del federalista, del jaurizta; o de la prensa liberal en Chile, la argentina, la ecuatoriana y, por supuesto, la cubana y 1898. Incluso se desplaza hacia la prensa brasileña y la publicada en los Estados Unidos, cuyo público lector engloba a chicanos, puertorriqueños y "latinos", o sea, hablantes de español como lengua materna.

En cuanto a los temas, encuentra espacio para hablar de la prensa modernista y vanguardista, del periodismo obrero, del taurino, sin olvidar el martirologio y los riesgos de ser periodistas, por ejemplo, en Guayaquil. Su historia no se limita a la

y opinión pública tras el desastre de 1898, Sevilla, E.E.-A., CSIC, 1996; Rafael Sánchez Mantero, José Manuel Macarro Vera y Leandro Álvarez Rey, La imagen de España en América, 1898-1931, Sevilla E. E. H-A., C.S.I.C. 1994.

39 Antonio Elorza, Once ensayos sobre la historia, Madrid, Fundación Juan March, 1976, J.T.A., Del viejo orden informativo, Madrid, ed. Actas, 1991.

40 Francesca Martínez Gallego, “La Revista de España....” en Mirta Nuñez Días-Bakart, et Al., José Altabella, Libro Homenaje, Madrid, Fac. de Ciencias de la Información-U. Complutense, 1997.

41 Diccionario de historia de España, dirigido por Germán Bleiberg, Madrid, Alianza editorial, 1979; Historia General de España y América, tomo xiv, La España liberal y romántica, 1833-1868, edicione RIALP, Madrid, 1983.

42 Antonio Checa Godoy, Historia de la prensa en Iberoamérica, Sevilla, Ediciones Alfar, 1993. 
prensa diaria, también comenta las revistas literarias, las teatrales y culturales, pasando por alto las de vanidades y entretenimientos. Su balance llega hasta la última década del siglo XX, con lo cual constituye una herramienta útil para quien desee información general. Sin embargo, cuando se considera la historia de la prensa en sus dimensiones comunicativas, como agente de control social o como creadora de relaciones entre los individuos menos aún entre las naciones, estamos ante otras posibilidades de la historia. Aquella escrita por la mirada del historiador, por la curiosidad científica del individuo que desde el presente se asoma al pasado, más que por cronologías y pruebas documentales. ${ }^{43}$

\section{CierTa MELANCOLía en el OCEÁNO}

En 1898, el Diario del Comercio, de Barcelona, publicó una colección de "Escenas Mejicanas" (sic) que habían aparecido parcialmente, "por entregas", en las páginas cotidianas del periódico catalán. A fines de año, como era costumbre, las escenas fueron recopiladas en $170 \mathrm{pp}$, y constituyeron, así reunidas, un volumen que tal vez fue obsequio de la redacción a sus lectores. En el año 2000, en la "Feria del libro antiguo y de ocasión" de San Lorenzo El Escorial, en Madrid, encontré, todavía circulando en el espacio público comercial del tercer milenio, esas $170 \mathrm{pp}$. Como estudiosa de la cultura letrada, siempre me ha sorprendido la vitalidad de las publicaciones periódicas, que trascienden sus orígenes, sobreviven a los autores reales, se desplazan por el planeta -evidencia de las primicias de la globalización- y uno o dos siglos después, todavía conservan la atracción, la seducción de toda primera plana. Los periódicos viejos, aunque cambie el formato, el sustento material, siempre encuentran lectores, lectoras. Casi siempre se alojan en estantes desde donde se muestran al público; y con paciencia acabarán por ser comprados nuevamente y puestos en circulación en un acto de mágica resurrección.

Desde fines del XVII y principios del siglo XIX, los editores de los periódicos idearon una serie de estrategias para atraer suscriptores y asegurar la venta de sus ejemplares. Se trata del nacimiento de la prensa como empresa y de la publicística que deja atrás, paulatinamente la tarea informativa, para fundamentar la ideológica $\mathrm{y}$, posteriormente, la de consumo. Contaban para ello con el potencial de la prensa que constituye el fundamento del llamado Cuarto Poder, descubierto desde el siglo XVIII: la fuerza de penetración en el imaginario individual, la capacidad de la prensa para representar los valores, ideales, necesidades y aspiraciones de los miembros de la comunidad. El poder de convocatoria cifrado en la habilidad para expresar lo que los individuos observan, la experiencia de la comunidad, experiencia que ella por sí

$43 \mathrm{~J}$. Herbert Altschull, Agentes de poder, La influencia de los medios informativos en las relaciones humanas,México, Publigraphics, 1988 . Altschull pertenece a la U. de Indiana, USA. misma no acierta a codificar. La necesidad de convertir en código la existencia misma explica la presencia del periodismo y sus funciones comunicativas.

Desde la apelación al imaginario individual, la prensa identifica, hilvana, tamiza y significa el imaginario colectivo. Alguien en Barcelona, en el siglo XIX, piensa en México; alguna otra, en los albores del tercer milenio lee "México" en España e identifica algo suyo: la prensa plasma el pensamiento de los individuos, convierte en sus páginas lo privado en público. El lector, la lectora se ve así representada sin importar límites de espacio, tiempo, culturas e ideologías. En toda lectura coexiste un proceso de identidad, de reconocer límites, fronteras con el otro o las otras. El poder de la prensa no se reduce a lo político, se expande hacia lo cultural, a nuestro modo de vida. El mexicano Emilio Rabasa, jurista chiapaneco nacido en 1856, quien llegara a ser gobernador de su Estado, Procurador General de la República y Senador durante la dictadura de Porfirio Díaz -aunque luego sufriera el exilio-, escribió una novela titulada El quinto poder, que es un clásico de la literatura mexicana. Aparece ahí el siguiente diálogo:

-¿Le parece a usted poco ser periodista, pertenecer al cuarto poder del Estado?

\section{-¿El cuarto poder?}

-El cuarto, sí señor. Algunos publicistas habían creído que debía existir un poder municipal, pero eso resultó una tontería; y estudios más profundos y la práctica, sobretodo, han venido a poner en claro que el poder único que puede y debe añadirse a los tres poderes sociales existentes y conocidos, es el de la prensa. Usted. Que no ha estudiado derecho público, no sabe nada de esto, ¡qué ha de saber!, pero yo le enseñaré en quince lecciones cuanto necesita para no quedarse callado en los corrillos más presuntuosos. El Congreso es representante de la voluntad del pueblo, ¿verdad?, pues la prensa lo es de la opinión pública. ¡Imagínese Usted representando a la opinión pública! Nada, no abrirá Usted la boca sin que sea en nombre de tal señora, que es persona decente, por más que ande en manos de todo el mundo. Esto es cómodo, porque la elección la hace usted mismo, y no dudo de el mundo. Esto sóm quedo, porsue la elecc té a Usted el director de La Columna del Estado, con un movimiento afirmativo de cabeza, pues no hay fórmula determinada para ese importante documento. ${ }^{44}$

En la actualidad, reducir la fuerza del Cuarto Poder a la capacidad para encumbrar o derribar personajes públicos es menospreciarla. La prensa forja la opinión pública,

44 Emilio Rabasa (1888), Cuarto poder, y Moneda falsa, edición y prólogo de Antonio Acevedo Escobedo, México, ed. Porrúa, 1990. p.42. En las sociedades republicanas, los tres poderes son el ejecutivo, legislativo y judicial. El cuarto poder constituye la alternativa social al monopolio estatal de la vida política, el término nace junto a, en los márgenes, de la concepción de estados federales y pactos parlamentarios. Por su condición de marginalidad, de no reconocimiento, de no oficialidad, el cuarto poder es también el poder de la disidencia, de la alteridad. 
no sólo la evoca o la representa; y con ello, domina el espacio público, por encima de partidos, Estados, riquezas y títulos nobiliarios. La opinión pública ocupa ese espacio con más éxito, en términos de preservación de las formaciones sociales, que las ideologías, las universidades o las iglesias. Estados vienen, partidos políticos van, ideologías sucumben, pero la prensa sólo tiene que contemplar el entorno, percibir los horizontes de expectativas de sus receptores, resignificar los contenidos, medir la eficacia de los mensajes mediante la retroalimentación y vuelve a entrar en circulación circuito de la comunicación completo cuando los lectores de épocas posteriores a la emisión del mensaje lo dotan de vida. Y es que el discurso de la prensa, merced a la fuerza apelativa en el proceso de comunicación, se afianza en el centro mismo del lector, en el imaginario colectivo, en las regiones simbólicas de lo sociocultural, en el fundamento de las relaciones de comunidad: en las señas de identidad.

Cuandoelhistoriadordelaprensaselimitaaconsiderarestrictamente"loinformativo", los datos cronológicos, nombres propios y comunes, ciertas construcciones discursivas pueden parecerle incomprensibles. Especialmente se sorprende de las divergencias entre la realidad que percibe y la representación de esa realidad que la prensa ha codificado. Dicho sea de otro modo, al leer periódicos viejos, hay que proceder con la lectura entre líneas. Así se les considera como agentes sociales, de las relaciones comunicativas entre los seres humanos, y no solamente como muestra estética, adorno del anticuario, ficha catalográfica en la biblioteca de una academia. ¡Qué mejor ejemplo de proceso comunicativo que los testimonios frecuentes de los historiadores de la prensa!. Un ejemplar de periódico, cuya materialidad se conserva en las hemerotecas, siempre puede contar con un lector -o lectora- para que lo resucite eventualmente. La prensa tiene una dimensión simbólica enorme, por ello trasciende los límites de espacio y tiempo. Una mirada hábil podrá desentrañar significados nuevos siempre. Al escribir su historia de la prensa, Rafael Sánchez Mantero, desde Sevilla, muestra cierta incomprensión adolorida -“y a pesar de todo ello”- de la imagen de España que encuentra en periódicos mexicanos:

México es uno de los países que mejor conserva su esencia hispánica y donde la huella de la presencia española puede advertirse de forma más clara. Además, en México, la afluencia de la emigración española fue muy importante en la etapa comprendida entre 1869 y 1931, (...) Y a pesar de todo ello, México representa el centro de una polémica pro-España anti-España, que en mayor o menor grado se produce en gran parte de los países del otro lado del océano. ¿Cuál es la razón de esta visión tan controvertida de España en México? ¿Por qué se dan en este pás

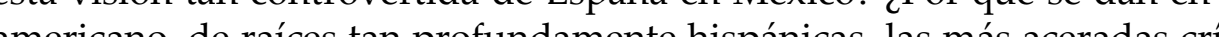
labor histórica de España y de los españoles en el Nuevo Continente?
Para tratar de responder a estas preguntas, es necesario comprobar hasta qué punto aparece distorsionada la imagen de España en México entre 1898 y $1931 .{ }^{45}$

Encuentro en este acercamiento una negación y un juicio ahistórico -“imagen distorsionada" - que disuelven el tratamiento científico e impiden contestar la pregunta misma del discurso: “¿cuál es la razón?". ¿Puede una opinión publicada “distorsionar" una imagen siendo que ella misma construye tal imagen? Comparto, no obstante, la curiosidad por observar las relaciones de atracción y rechazo, la ruptura y continuidad en los juegos amorosos entre México y España, especialmente cuando tales relaciones quedaron plasmadas, se ven materializadas en la prensa del siglo XIX y circulan por el corredor cultural.

Las "Escenas Mejicanas" -y las disfruté aunque estuvieran escritas con "j"- me atrajeron porque evocaban las palabras que Sánchez Mantero escribiría casi un siglo después. Son parte del discurso que se escucha, reverbera y se convierte en eco, circula y se retroalimenta con emisiones americanas y europeas, españolas y latinoamericanas, constituyendo una expresión plenamente iberoamericana, en ambos lados "del océano" de Sánchez Mantero, alusión involuntaria al corredor transatlántico. El corredor explica que Luis de Bellemare, el autor de las escenas que publicara El Correo del Comercio a fines del siglo XIX, expresara también una incomprensión adolorida cuando contempla la presencia española, la huella europea en México:

De todas las ciudades edificadas por los españoles en el Nuevo Mundo, Méjico es indudablemente la más bella y Europa podría enorgullecerse de contarla en el número de sus capitales. El que se proponga contemplar en todo su esplendor el raro y magnífico panorama (...) no tiene más que subir un poco antes de la puesta del sol a una de las torres de la catedral. (...) Todo eso no constituye más que . Por consiguiente, poc los objetos leas y las grandes ejecutivo y legislativo, municipio, comercio, en una palabra, toda la organización mejicana se encuentra concentrada en algunos edificios que la iglesia parece cobijar bajo su sombra protectora. El pueblo se encuentra también allí, (...) una corriente humana que se muece y remuece. Basta permanecer algunos instantes confundido entre esa muchedumbre para conocer la sociedad mexicana en su más raros contraste de vicios y virtudes, de lujo y miseria. ${ }^{46}$

La percepción española de cierta ingratitud mexicana, y de ciertos rasgo incomprensibles para el europeo, apareció de nuevo, como una perpetuación, en dos textos de una publicación periódica del año 2000. Desde Madrid, como comentario a la noticia "España supera a USA en Iberoamérica", dice Eulogio López: "Precisamente

45 R. Sánchez Mantero, “La imagen de España en México”, en Op. Cit, p. 197.

46 Luis de Bellemare, "Escenas Mejicanas", Folletín del Diario del Comercio", T. II, Barcelona Imprenta del Diario del Comercio, Calle de Cortes, Granvía, 132, bajos, 1898, p. 1 a 4 . Empastado a uso de las bibliotecas familiares, con Jorge Mc Donald, Guild-Court, Biblioteca de La Vanguardia Barcelona, Imprenta de La Vanguardia, calle de Pelayo No, 28, 1906, 302 pp. 
es México el país hispano que más se ha resistido a la inversión española, el más proclive a relacionarse con el gigante del norte. Las empresas españolas siempre se han encontrado dificultades para instalarse en ese país. México es la zona de sombra de Telefónica, Endesa, BSCH o Repsol."

Mientras que, páginas más adelantes, al comentar las telenovelas, ese subgénero literario, Alfonso Ussia declara: "México es el gran productor de telenovelas, pero me temo que su estética nada tiene que ver con la mía. Me agobian sus diálogos, rebosantes de cursilería. En una telenovela no importa el argumento, que siempre es el mismo, sino el gusto de la palabra." ${ }^{47}$ Desde 1896, retumba un eco del Madrid Cómico, el periódico semanal, festivo e ilustrado, que circulaba en "Madrid, Provincias y Ultramar". Desde la columna "De todo un poco", escribe Luis Taboada, en la sección titulada "Ripios Ultramarinos", una diatriba "contra los jóvenes americanos que publican revistas literarias sin ton ni son", una queja de la Revista Azul. O bien, dos años más tarde, se publica un artículo de Jacinto Benavente contra el modernismo, primer movimiento literario originado en el Continente Americano, parteaguas del "gusto de la palabra" latinoamericana. ${ }^{48}$

Y recuerdo las lecciones de Bourdieau acerca de la gratuidad en las acciones sociales, las públicas que engloban las publicadas:

Más aún, encuentro una respuesta, la contraparte a esa melancolía española cifrada en el mundo de la prensa con más de doscientos años de diferencia, del otro lado del océano, en México. Allí, añoranza e ingratitud se convierten en desaire. En 1890 el poeta Manuel Gutiérrez Nájera, fundador de las Revista Azul y Revista Moderna, impulsor del modernismo mexicano, reflexionando acerca de la originalidad de la literatura nacional -de nuevo las palabras, eco de Ussía-, justifica el uso de la lengua española al modo mexicano, al modo universal, y publica en la prensa porfiriana un artículo medular para el modernismo, "El cruzamiento de literatura". Sus argumentos del libre acceso al acervo literario son un preludio de la actual intertextualidad. Pero el poeta modernista, editor y corresponsal de Rubén Darío,

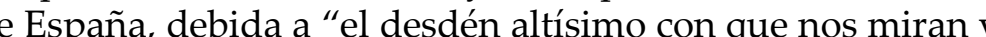
la impremeditación con que nos juzgan" 49

47 E. López, sección “La ruta del dinero", $2^{\mathrm{a}}$ nota, pp. 25-27; A. Ussía, Col. “Prisas, prosas y pausa Telenovelas", p. 47, Época, No. 786, 19 de marzo de 2000, Madrid.

48 Madrid Cómico, Periódico semanal, festivo e ilustrado, año 8, director Sinesio Delgado, 13 de junio de 1896. HMM, F. 10/13.

49 Rep. Por Belém Clark de Lara, "Manuel Gutiérrez Nájera, El cruzamiento de literatura", en Ruedas de la Serna, Op. Cit. (1996) , p. 401. Ibidem los debates de la originalidad, según J.M. Vigil, y del desdén y la impremeditación española denunciada también por L. González Obregón y J.M. Roa Bárcena, quienes en la prensa se preguntaban por qué Mercelino Menéndez y Pelayo había ignorado las sugerencias enviadas por la Academia Mexicana. El debate sigue, Cf. J.L. Martínez, Unidad diversidad de la literatura latinoamericana, México, Joaquín Mortiz, 1979.
Recuerdo el discurso de la desespañolización liberal, el del desdén modernista, e de los desaires e ingratitudes; y del corredor cultural emergen, desde 1694, imágenes mexicanas de la "poca generosidad" de España para quienes viven en la Nueva España:

Madrastra nos has sido rigurosa,

y dulce madre pía a los extraños

con ellos de tus bienes generosa

con ellos de tus bien generosa,

con nosotros repartes de tus daños

Ingrata patria, adios, vive dichosa,

Con hijos adoptivos largos años,

Que con tu disfavor fiero, importuno

Consumiendo nos vamos uno a uno. ${ }^{5}$

Acto seguido recuerdo que, a pesar de la "imagen distorsionada" que percibe Sánchez Manero, del 4 al 17 de enero de 1900, en El Tiempo, de Ciudad de México, aparecieron más de 10 artículos de fondo promoviendo la idea de un "frente de unión entre los países latinoamericanos y España", un frente antiestadounidense ${ }^{51}$. Y según un historiador contemporáneo -que no coetáneo- de S. Manero, desde 1898:

En su conjunto, los editoriales de la prensa apoyaban el movimiento de la independencia de Cuba en contra de España, pero cuando se inicio el conflicto entre España y los Estados Unidos, apoyaron a España en contra de los Estados Unidos y objetaron la influencia estadounidense en Cuba. En el Congreso de Madrid que se celebró en 1900, se reunieron representantes de las naciones hispanas con el fin de establecer la cooperacinn hispanica. (...) En la prensa se sugirio que ( (Diario del Hogar, sept. 2 de fortalecimiento de la unidad frateral entro de progreso y las relaciones internacionales. Sobre bases pragmáticas e idealistas se pugnó por lograr la cooperación latinoamericana e hispánica, es decir, la protección mutua y la afinidad cultural..$^{52}$

Precisamente la afinidad cultural es el armazón del corredor cultural por donde circulaban entonces y ahora ideologías compartidas y debatidas que se materializan en representaciones en ambos lados del Atlántico, en citas indirectas, imaginería, emblemas, símbolos, en fin. A la historia de la prensa le interesa conocer a los gestore o las gestoras del corredor, a las codificadoras de esas afinidades. Por ejemplo, a Concepción Gimeno de Flaquer, una aragonesa que con éxito comercial dirigió en la Ciudad de México EL álbum de la mujer, Periódico ilustrado, como directora propietaria, en la imprenta de Francisco Díaz de León, de 1883-1890. O a Emilia Serrano de Tornel Baronesa de Wilson, nacida en 1845 en, Granada, que vivió en América 6 años y que fundó en México El Continente Americano. Sorprende que esta baronesa escribiera

50 Baltasar Dorantes de Carranza, Sumaria relación de las cosas de la Nueva España, México, Museo Nacional, 1902. (transcripción de J.A. Ágreda del MS de 1604), p. 234

51 N. Pérez Rayón, Op. Cit., p. 126

52 Juan Gómez Quiñones, Los intelectuales... México, Ediciones El Caballito, 1981, p. 151. 
para el liberalismo mexicano, antomonárquico y anticlerical, el volumen México y sus gobernantes.

\section{PRENSA Y HOMONIMIA DE AMBos MUNDOS}

Por el corredor transita una migración de ideas materializada en los títulos de la prensa de ambos mundos, opinión pública consciente de la existencia del otro. Acto comunicativo donde el referente se desplaza por un espacio sociocultural llamado hispano-mexicano o hispanoamericano donde se comparten referentes, signos y símbolos a pesar de que los lugares de enunciación sean diversos. La afinidad entre las alteridades, los procesos de identificación pueden verse en los campos semánticos transatlánticos, signos de ambos mundos, el Nuevo y el Viejo, dinámica ultramarina. El prototipo sería el Eco de Ambos Mundos, célebre periódico español del siglo XIX, destinado a proporcionar la información de esta región sociocultural. La Crónica de Ambos Mundos, que el asturiano Gonzalo Castañón dirigía en Madrid, en 1861, es también prototípica. De este tenor son también publicaciones como La América, de principios de siglo y la también célebre Ilustración Española y Americana, que inicia a mediados de siglo y dura muchas décadas o el Álbum Iberoamericano, de 1873, donde publicaban obra de autoría americana cuyas páginas constituyen ese imaginario compartido. Se trata de la prensa americanista en España: periódicos y revistas acerca de asuntos latinoamericanos.

\section{PRENSA AMERICANISTA DE MADRID ${ }^{53}$}

En México circuló, de 1871 a 1876, el paradigmático Eco de Ambos Mundos, periódico de religión, política, literatura y ciencias. Fue redactado durante su primera época por José Tomás de Cuéllar, José María Vigil y Alejandro Argándar De tiraje quincenal al principio, la redacción decidió convertirlo en semanal en 1872, el mismo año en que "comenzó a editar un suplemento literario dedicado al público femenino". Colaboraron en esta nueva etapa los miembros de la Sociedad Literaria El Porvenir, entre ellos Joaquín Alcalde, Lorenzo Elízaga, Francisco G. Cosmes y Juan de Dios Peza". ${ }^{54}$ En 1873, como parte de la "Biblioteca del Eco de Ambos Mundos", aparece Flores del Siglo, una antología de poesía femenina preparada por célebre editor: Juan. N. Barbero, en cuyo prólogo asienta la afinidad de las alteridades:

53 Fuentes: investigación personal y Carlos M. Rama, Op. Cit y M.C. Seoane, Op. Cit. Razones de espacio reducen los ejemplos. Dos fechas entre guiones indican inicio y cierre de la publicación; una fecha indica el año que encontré adjunto a la información acerca de la prensa, no necesariamente que sólo circuló en ese año. 54 Emmanuel Carballo, Historia de las letras mexicanas en el siglo XIX, Universidad de Guadalajara/ Xalli, Jalisco, 1991, p. 310
Hemos procurado que nuestra compilación contenga lo más hermoso de las liras americana y española. Nuestra pretensión fue más allá de presentar a los lectores del Eco de Ambos Mundos, un cuadro digno de guardarse en la admiración más tierna. Ellas tienen bastante mérito para brillar en nuestro siglo; además contienen una hermosa página de historia moderna y una sonrisa para el porvenir. ${ }^{55}$

En los diversos volúmenes de Flores del siglo, se recoge la obra publicada en el periódico, de escritoras de ambos lados del Atlántico. Tal era la intención: unir los dos continentes, presentar vida y cultura trasatlántica como premoniciones de la globalización. Junto a poetisas de España y Cuba como la Baronesa de Wilson, Carolina Coronado, Gertrudis Gómez de Avellaneda, Luisa Pérez de Zambrana y otras, aparecieron publicadas 18 mexicanas en el Eco de ambos mundos. En México, se editan periódicos con los ojos y los oídos atentos a lo europeo, más precisamente a lo peninsular, en correspondencia con los afanes madrileños puestos en América, en México. Aunque, El Pabellón Español proclamaba "periódico exclusivamente dedicado a la defensa de los intereses españoles", no todo es prensa para la "colonia española" avecindada en América. Ojos mexicanos también se ven representados en esa opinión publicada. Las raíces entrelazadas impiden, a veces, distinguirse a unos de otros.

\section{PRENSA ESPA ñolista en MÉxico}

Esta migración de ideas es notable ya desde las hojas volantes y folletería, como "Lamentos de la desgraciada sobrina de un canónigo", las numerosas impresiones americanas sobre la situación española de 1808, hecho que impactó profundamente en las Colonias y que es pieza clave en la Independencia de los pueblos americanos, como "Desafío del europeo al americano" o "El amigo de todos". Multitud de folletos pulularon entre la incipiente opinión pública, después de que por ambos continentes se desparramaran las libertades de imprenta, tan discutidas, en las Cortes de Cádiz. El corredor verifica que José Joaquín Fernández de Lizardi, primer novelista y famoso pionero del periodismo mexicano, prolífico autor de principios de siglo, célebre por sus escritos satíricos, lo transitó y se vio representado en él. Su epíteto de "El pensador mexicano" era también el nombre de célebre periódico. Preso por delitos de imprenta repetidas veces, supo de la existencia, o leyó a La Pensadora Gaditana ${ }^{57}$, anterior en el tiempo (1763) y en estilo irónico. Toponimia y estilo compartido también con El Pensador de Madrid, publicado por primera vez en 1762.

55 Barbero, Juan E., Flores del siglo, Album de poesías selectas de las más distinguidas escritoras americanas y españolas, (coleccionadas por...), México, t. I, Imprenta de Ignacio Cumplido, calle de los Rebeldes Número 2, Biblioteca del “Eco de Ambos Mundos”, 1873, T. I 543 pp.

56 Investigación propia, y M.C. Ruñiz Castañeda, El periodismo en México...Op.Cit, y Checa Godoy, Op. Cit.

57 Cinta Canterla, (edición antológica), La Pensadora Gaditana por Doña Beatriz Cienfuegos, Cádiz Universidad de Cádiz, 1996 
El corredor tiene en España un edificio donde quedó depositado parte del capital la Hemeroteca Municipal de Madrid. Ahí se conserva la versión mexicana de El duende de los cafés, que aparece en México muy pronto, en 1820, también del mismo año es la Miscelánea de Comercio, artes y literatura. Ambos periódicos mexicanos, cuentan con antecedentes españoles al igual que los Correos, Los Momos, Las Gazetas, Los Diarios del Hogar, Los Republicanos, Los radicales, Los Censores, Imparciales, Monitores Republicanos, Siglos XIX, Enseñanzas, Instructores, Opiniones, Boletines, Porvenires, Tiempos, Naciones, etcétera. Y la homonimia se extiende por Ecuador hasta la Patagonia. Se trata de apropiaciones y préstamos culturales que mirados más allá de los intereses imperialistas o hegemónicos, revelan una comunicación fructífera, afinidades expresivas que rebasan lo dialectal para manifestar imaginarios compartidos, así como mentalidades de la época.

En Cuba, México y Bogotá, en Lima, Buenos Aires y Caracas, igual que en Madrid, Valencia y Bilbao existen Abispas, Abejas, Zurriagos, Lobos, y luego Revisores Políticos, Imparciales, Amigos y Defensores del pueblo, Renacimientos, Concordias, Variedades, y, no podían faltar los Álbumes y las Violetas, Las Regeneraciones, los Gil Blases y los impúdicos Burros. No importan tanto los orígenes de esta tradición como las repercusiones y evidencias en términos de intertextualidades, de unión en ambos lados del Atlántico. Tampoco importa en este punto, el argumento de que la prensa liberal española era copia de la francesa ${ }^{58}$. Seguramente, la migración de ideas se dio en una región simbólica que se superpone a la trasatlántica, Iberoamérica, de la Península al Continente y viceversa.

\section{PALIMPSESTOS ESPAñoleS EN PERIÓDICOS MEXICANOS}

La riqueza del acervo ultramarino de Madrid ha sido compilada en un catálogo y está, en su mayoría microfilmado para que los nuevos lectores revitalicen el discurso. Esos fondos, cuya historia es difícil de trazar pues los registros de entrada se perdieron durante la Guerra Civil, revelan una voluntad social por conservar

un conjunto de publicaciones iberoamericanas -en proporción muy mayoritaria provenientes de México, Cuba y Argentina- no exhaustiva, porque la prensa iberoamericana es abundantísima, exuberante, poco menos que inabarcable, como se echa de ver compulsando bibliografías. Pero sí es bastante representativa como para poder contribuir a un fértil acercamiento a la cultura de las tierras que, de alouna suerte, son prolongación de la Peninsula comola Peninsula lo es de ellas. ${ }^{59}$

58 Por ejemplo, tanto en México como en España existió la tercera década del siglo una Minerva. primero la existencia de la española.

59 Carlos Dorado (dir.), Catálogo de Publicaciones Iberoamericanas de los siglos XVIII y XIX, Madrid Hemeroteca Municipal de Madrid, 1998.
Tras la técnica catalográfica, existe un discurso historiográfico que acusa una propuesta cultural, una dinámica relacional. Buena parte se constituyó de donaciones de particulares, de americanos que pasaban por España, aunque la mayoría proviene de lo aportado por los países americanos para constituir el Pabellón de Prensa Iberoamericana, a invitación de la Hemeroteca, que lució en la Exposición de Sevilla de 1929. Tras la Exposición, los latinoamericanos cedieron lo expuesto a Madrid. Hubo después de 1939, una incautación de bibliotecas particulares, y todas las publicaciones periódicas fueron cedidas a $\mathrm{HMM}^{60}$. ¿Qué criterios seguiría la Junta de Recuperación Bibliográfica, c. 1939, al seleccionar la prensa para destruirla o conservarla? Lo que logró escapar a la destrucción franquista constituye, de por sí, un objeto de estudio: reflejo de la mentalidad de otra época y de sus virtudes relacionales. $\mathrm{Si}$ es cierto que la prensa mexicana en HMMM ocupa el primer lugar en volumen, no lo es menos que lo conservado corresponde mayoritariamente a la ideología liberal del proyecto nacionalista, a la opinión publicada de lo radical, anticlerical, antimonárquico, aquella que propugna por la "desespañolización". Desde LA ABISPA (sic) de Chilpancingo, conmemorativa de la "buena memoria" de Morelos, padre de la Independencia, hasta El Alacrán, periódico aspirante a subvencionado -1899, antiporfirista, antecedente de la Revolución Mexicana, clandestino, emitido desde la cárcel desde la $3^{a}$ edición- pasando por El Indio Constitucional (1820) El Atalaya del gobierno, y amigo sincero del Presidente de la Federación, (1825); La Sombra de Moctheuzoma Xocoyotzin (1834), La Oposición: Federación y Unión (1834-1835) o El Independiente (1847).

En particular es notable la subsistencia de El Precursor, un semanal que se publicó de 1874 a 1875, durante el periodo del Liberalismo Triunfante, entre las presidencias de Juárez y Porfirio Días. A cargo de Ignacio Ramírez, I. M. Altamirano, Telésforo García, Justo y Santiago Sierra, su lema era: "Debe decirse la verdad aunque sea origen de escándalo". Ninguna historiografía da noticias de este impreso singular, abiertamente "librepensador en cuanto al desarrollo de las ideas y libre-cambista en cuanto al ejercicio de la actividad humana", que en su Introducción propone:

libertad para la conciencia, libertad para la investigación, libertad para las manifestaciones de nuestro ser bajo el punto de vista de la razón y la verdad (...) librepensador por excelencia, El Precursor sera un periodico especialmente crítico que buscará la justicia, la verdad, el bien y la belleza en todas las instituciones sociales y en todos los productos de la humana inteligencia. Toda buena causa tendrá el él su defensor $(\ldots)$ toda buena acción su aplauso. Todo trabajo que implique adelanto en cualquiera de más entusiasta y sincera. ${ }^{61}$

60 Entrevista personal a Carlos Dorado, 28 de agosto de 2001. Madrid.

61 Telésforo García, El Precursor, 8 de octubre de 1874, México, año 1, No. 1, p. 1. 
El ejemplar que tuve a la vista tiene anotaciones al margen de puño y letra de un lector: la caligrafía y el estilo, así como el léxico -las palabras de Ussía- parecen españolas. Este lector instruido compartía y debatía las ideas del Precursor. Además de ser un masón, como los redactores, puede haber sido maestro, pues las anotaciones a margen ${ }^{62}$ corresponden con enmiendas subsiguientes que el impresor mexicano, Ignacio Cumplido, corregirá como buen discípulo. El contenido del periódico corresponde con las prácticas transculturales del corredor aquel. Es rotundamente antieclesiástico anticatólico, y reproduce tendencias del pensamiento liberal español, el adyacente al canon isabelino. Cita, por ejemplo, "al diputado español Moret y Pendergast que ha dicho: "Hombres del pasado, si queréis oponeros a la marcha triunfante del carro de la revolución, las ruedas de ese carro pasarán por encima de vosotros, segando vuestras gargantas". (p. 1)

Abundan las críticas contra, por ejemplo, la mística Ciudad de Dios, de la madre Jesús de Ágreda, o la murciana Cruz de Caravaca, y anuncian "el próximo artículo que Emilio Castelar publicará en la Revista Europea de Madrid (7 de marzo de 1875) acerca de la cuestión religiosa en Alemania". Es, en fin, una prensa que corresponde con la propuesta de I. Ramírez de que Castelar se desespañolice: desespañolizar equivale a anular lo monárquico. Así pues, más que adherirse al canon isabelino, el capital cultural iberoamericano de HMM se aleja de una negación o una separación de España, y parece conjugarse en torno a los proyectos de independencia, de libertad, de democracia, diríamos ahora. ¿No era la libertad, la independencia el afán en la prensa decimonónica de América Latina?

El periódico masón anunció desde su primer número que trataría de "Ciencias, artes, literatura, religión y comercio, industria y de cuantas materias puedan interesar al movimiento intelectual y material del país. Su criterio es librepensador en cuanto al desarrollo de las ideas y libre-cambista en cuanto al ejercicio de la actividad humana". Aunque la mención del pensamiento librecambista pudiera llevarnos a asociar esta opinión pública con la estadounidense, el diálogo internacional de El Precursor tiene a España, o más precisamente, a lo español, por interlocutor. Además de las referencias a congresistas españoles y el enfrentamiento con la mística peninsular, están las columnas de Martínez del Romero donde semanalmente analiza, pondera o critica la literatura española. Por ejemplo, la del 8 de octubre de 1874, está dedicada a destrozar -tópico romántico-el soneto "Oh dulces prendas por mi mal halladas" de Garcilazo de la Vega. Cuando se publican poemas, gusto de la prensa romántica, los únicos extranjeros son peninsulares, como la poesía "Un familión" de Bretón de los Herreros (p. 14). Otra columna notable es la del "Examen de las sagradas escrituras" por Rabí Abben Ezrah,

62 Por ejemplo: se permite escribir, con tinta sepia, en la edición del 122 de julio de 1875: “El bárbaro del impresor cortó el artículo estúpidamente, al modo que está, bestias". opinión pública judaizante de procedencia sefardí. En los artículos para denunciar "los errores, disparates y mentiras piadosas de las vidas de los santos", por ejemplo, abundan los sitios españoles, como el de "La Cruz de Caravaca". Y en su desarrollo siempre se menciona la ubicación: "la que está en Murcia, España". O bien, “Los ojos de Santa Lucía", que empieza con "Cierto andaluz sevillano" y remata afirmando que del monumento "Aun hay otro en Sevilla". Se ostentan como "Versos Carlistas" los dedicados "A la profesión de un neocatólico". Por supuesto que abundan los chistes contra curas salaces, "que tienen dos de 20 para hacer una de 40 ".

El original de HMM contiene palimpsestos que con tinta sepia mejoran o modifican lo impreso en México. Por este corredor cultural, circulan abundantes señas de identidad entre España y la otrora Nueva España. En una sátira de las guanajuatenses que se apersonaron en tal Congreso estatal, el redactor las iguala retóricamente con mujeres españolas, y establece incluso las coordenadas, dos en México, dos en España:

\section{A las señoras de Guanajuato: ¡Bravísimas ilustres Manolas! ¿Pues no hemos creído al leer vuestra propuesta al soberano Congreso de la Unión, que estábamos en el Barrio del Perchel de Málaga, en el de Triana de Sevilla, o en el de La Palma de México?.}

Estos palimpsestos (;Bestias!) anuncian los cambios que el impresor mexicano Ignacio Cumplido, realizará en números siguientes con la disculpa reverente, tan propia del ceremonial mexicano prehispánico "Por uno de esos errores". Lo que interesa aqui son los aciertos comunicativos verificados en esta correspondencia. Otros periódicos confirman tal correspondencia, y la Hemeroteca Municipal de Madrid lo corrobora en el catálogo, Publicaciones Iberoamericanas de los siglos XVIII y XIX,

Un conjunto de publicaciones iberoamericanas -en proporción muy mayoritaria, provenientes de México, Cuba y Argentina- no exhaustiva porque la prensa iberoamericana es abundantísima, exuberante, poco menos que inabarcable. (...) Pero eso sí, bastante representativa como para poder contribuir a un fértil acercamiento a la cultura de tierras que, de alguna suerte, son prolongación de la Península, como la Península lo es de ellas. ${ }^{63}$

Me apresuro a refutar puntualmente cualesquiera explicaciones pro imperialistas o visiones eurocentristas. Ya el Catálogo establece la reciprocidad del vínculo. Me parece conveniente anotar los tres hitos comunicativos evidentes en la presencia periodística: México, Cuba y Argentina. ¿Por qué esos tres países? Si el estudio de las prácticas intertextuales iberoamericanas muestra el gusto literario aquel, también habla de representaciones mentales e imaginarios españoles, no solamente latinoamericanos. Una mirada cuidadosa al acervo cubano y argentino encontrará significados que no

63 C. Dorado, "Preámbulo", Publicaciones Iberoamericanas de los siglos XVIII y XIX, Catálogo de la Hemeroteca Municipal de Madrid, Concejalía de Cultura, Madrid, 1998, p. 20. 
saltan a la vista. ¿Qué piensa España de estos tres países? Las afinidades entre España y México son muy profundas, tanto que éste fuera designado en el imaginario español como la Nueva España: cuestiones de identidad.

En agosto de 1899 apareció en la Ciudad de México, El Alacrán, periódico aspirante a subvencionado, hábil sátira política contra la reelección de Porfirio Díaz. Además de fecha emblemática del fin de siécle y de las vanguardias para Occidente, para el mundo de habla hispana, 1899 marca el período de duelo para España por la pérdida de las últimas colonias en América, tanto como el esplendor expresivo de la generación del 98, del modernismo y de las reflexiones acerca de la identidad hispana, y, por extensión, de lo hispano-americano. La emisión coincidía con el plazo de preparación de las elecciones municipales, estatales y presidenciales de la República Mexicana. Se justificaba pues la "apoyaba" la candidatura de Joaquín de la Cantolla, el tesorero de Don Porfirio. El conocido magnate, famoso por sus estrafalarios vuelos en globo, se apresuró a desmentir tal candidatura en periódicos realmente subvencionados. La sorpresa aumenta con la vista del monumental documento: cuatro pliegos enormes, impresos a dos tintas, con anuncios pagados y artículos de opinión, noticias y entrevistas; textos profusamente ilustrados con caricaturas que rebasan el estilo iconográfico acostumbrado en la época y el lugar. Todo ello sugiere una expresión insólita en tiempos de la augusta "Paz Porfiriana", cuando el país dormitaba tras cas dos décadas del gobierno de Don Porfirio, y una anterior a la Revolución Mexicana.

La serie completa, los 37 números que el llamativo Periódico aspirante a subvencionado alcanzó a emitir, reposan íntegros en el acervo de la Hemeroteca Municipal de Madrid ${ }^{64}$, en perfecto estado de conservación, mientras que en el depósito oficial del espacio público originario, la Hemeroteca Nacional de México, solamente se conservan unos cuantos números sueltos, debido a la censura. Según informan los propios periodistas, desde el segundo número fueron denunciados y en el tercero, encarcelaron al director y redactores responsables. Sin embargo, el número 3, del 16 de septiembre, alcanzó a salir, con dos días de retraso. Desde la siniestra Cárcel de Belén donde recluían a los presos del orden común, siguió imprimiéndose y aspirando a ser subvencionado, hasta que pasaron las elecciones. El Alacrán tuvo la subvención, pero no del gobierno, sino de otro grupo formado por los jóvenes modernistas, los burgueses incipientes que miraban hacia Europa desde los llanos de Apan. Contenido

64 Catalogado bajo la signatura F 45; en la sección "Varios periódicos de México" se encuentran los 37 números de El Alacran. El director de la HMM, Carlos Dorado, el director, y Matilde Pérez documentalista, tuvieron a bien mostrármelos en abril de 2000, como uno de los tesoros de la Hemeroteca no sólo por la lujosa edición, también por la belleza de las ilustraciones. Sabían que en México no se conserva la colección completa pues en visita anterior de la entonces Directora de la Biblioteca y Hemeroteca Nacionales de México, María del Carmen Ruíz Castañeda, lo habían comentado. La colección ha sido restaurada recientemente y una vez me permitieron ver los originales. satírico y mordaz, iconografía esperpéntica y abiertamente sexual, tan contrario a los lemas porfiristas de "Paz y Progreso" primero, y luego "Orden y Progreso", nos lleva a compararlo con la tradición del madrileño El Acábose, o el Madrid Cómico y El Gedeón.

Que en Madrid se conserve esta singular prensa mejor que en México señala la dinámica del capital cultural de la región sociocultural llamada Iberoamérica. Como en el caso de El Precursor, existe un referente español para el discurso de ALA, evidente en expresiones como el epígrafe:

Así me gustan / Los gachupines,

Siempre en su puesto/ Tercos y firmes (...)

¿Ves, Mercenario?/ No le des vueltas (...)

Nadie en su patria/ Llega a profeta. ${ }^{65}$

O como las siguientes expresiones que desde el primer número, suponen a un lector que conoce la región simbólica de lo Peninsular:

“No olvidemos que aquí, como en La Marcha de Cádiz, le mandan a un periodista a la cárcel con corazón y todo" ( 27 de agosto, p. 3 )

"Música de cabezudos sin gigantes" (pie de ilustración, 27 de agosto, p. 4)

"como en la pieza "Los de Cuba", que se estrenó en Madrid, unos 12 años antes" ( 27 de agosto, p. 4)

"Canciones a las que se les puede poner cualquier música de zarzuela chica española" (título de unos versos contra el gobernador del Estado de Michoacán, 3 de septiembre, p. 3)

"Brindis del andaluz o del cordobés" (pie de ilustración, 3 de septiembre, p. 4)

“El obispo de México visitando la catedral de Burgos (ilustración 3)

Al referente español, puede añadirse el lujo de la edición. En efecto, ALA es un periódico de élite, de diseño monumental por su tamaño en cuarto, por las impresiones a dos tintas, de color rojizo y negro, con principios de mercadotecnia pues los anuncios pagados se entreveran con artículos de opinión, noticias y entrevistas, que oscilan de la formalidad a lo banal, de la seriedad a la burla. Sobresale de otros periódicos satíricos por sus textos profusamente ilustrados con caricaturas que rebasan el estilo iconográfico acostumbrado y que llegan al escándalo del travestismo al vestir de mujer a Don Porfirio o a sus ministros. El tópico españolista en las imágenes, tanto como la procedencia de sus anunciantes o el hecho de que redactores e impresores conserven el anonimato, o recurran a seudónimos, constituyen una expresión insólita en tiempos de la augusta "Paz Porfiriana", cuando el país dormitaba tras casi dos décadas del gobierno de Don Porfirio, y una anterior a la Revolución Mexicana. El Alacrán originado en México, transitando con osadía entre la censura porfiriana y atravesando la crisis española de 1898, para ser conservado en la Hemeroteca más importante de Madrid, es una joya del capital cultural de la región sociocultural llamada Iberoamérica.

65 El Alacrán, periódico aspirante a subvencionado, Ciudad de México, 27 de agosto de 1899, p. 3. "Gachupines" es un mexicanismo, gentilicio de los oriundos de España, que conforme avanzó el iglo XIX perdió su connotación despectiva para convertirse en un término familiar, comparable a la designación peninsular de "guiri" para los hablantes de inglés. 
Más que las prácticas del periodismo, el objeto de estudio revelado en estas páginas está constituido por la "prensa de Ambos Mundos", una parte del capital simbólico que une a estas dos naciones, capital que circula de uno a otro lado del Atlántico transportando bondades de una a otra orilla, acortando las distancias, borrando las diferencias y disidencias.

\section{BIBLIOGRAFÍA}

Altschull, H. (1988). Agentes de poder, La influencia de los medios informativos en las relaciones humanas.Publigraphics, México.

Barrera López, T. (1986). "La identidad cultural americana a finales del siglo XIX", Andalucía y América en el siglo XIX, T. II, Escuela de estudios hispanoameicanos-Universidad hispanoamericana de Santa María La Rábida: Sevilla.

C. Dorado, C. (1998). "Preámbulo", Publicaciones Iberoamericanas de los siglos XVIII y XIX, Catálogo de la Hemeroteca Municipal de Madrid, Concejalía de Cultura: Madrid.

Cordero, E., Torres. (1974). Historia del periodismo en Puebla (1820-1892). Ed. La Bohemia Poblana_México.

Del Carmen Reyna, M. (1976). La prensa censurada durante el siglo XIX. Secretaría de Educación Pública: México.

M. Rama, C. (1982). Historia de las relaciones culturales entre España y la América Latina. Siglo XIX, Fondo de Cultura Económica: México.

Mc Gowen,G. (1978). Prensa y poder, 1854- 1857. El Colegio de México: México.

Robert Ross, S. (1965). Fuentes de la historia contemporánea de México, Periódicos y revistas, El Colegio de México: México.

Ruíz Castañeda, M.C, Márquez Acevedo, S. (1985) Catálogo de seudónimos, anagramas, iniciales y otros alias usados por escritores mexicanos y extranjeros que han publicado en México. UNAM: México.

Sánchez Llama, I. (2000) Galería de escritoras isabelinas, La prensa periódica entre 1833 y 1895, Ediciones Cátedra -Universidad de Valencia- Instituto de la Mujer: Valencia.

Schneider, L. M. (1973). Ruptura y continuidad, la literatura mexicana en polémica, Fondo de Cultura Económica: México.

Sierra, C. J. (1962). La prensa liberal frente a la Intervención y el Imperio. Secretaría de Hacienda y Crédito Público: México.

Victoria, E. (1996) “Ignacio Ramírez, La desespañolización” en Jorge Ruedas de la Serna, coord. La misión del escritor, ensayos mexicanos del siglo XIX, México, UNAM. 